\title{
THE SYNTHESIS OF A NOVEL BIBENZOPYRAN RELIED ON ELECTROOXYDATION OF MALLOAPELTA B BY CYCLIC VOLTAMMETRY
}

\author{
Phan Thi Binh*, Bui Hai Ninh \\ Institute of Chemistry, VAST, Vietnam \\ Chau Van Minh, Nguyen Hoai Nam, Le Mai Huong, and Phan Van Kiem \\ Institute of Natural Products Chemistry, VAST, Vietnam
}

Received 17 October 2005

\begin{abstract}
A novel bibenzopyran named bimalloapelta (1) was synthesized relying on electrooxydation of malloapelta $\mathrm{B}$ by cyclic voltammetry in acetonitril adding $\mathrm{LiClO}_{4} 0.1 \mathrm{M}$ as supporting electrolyte. Its structure determination based on extensive NMR studies and ESI mass spectral measurements. The new compound showed significant cytotoxicity againsts two cancer cell lines as human hepatocellular carcinoma (Hep-2; $\left.\mathrm{IC}_{50}: 0.46 \mu \mathrm{g} / \mathrm{m}\right)$ and rhabdosarcoma (RD; $\left.\mathrm{IC}_{50}: 0.33 \mu \mathrm{g} / \mathrm{m}\right)$. These results were the same that of malloapelta B (Hep-2, $\mathrm{IC}_{50}: 0.49 \mu \mathrm{g} / \mathrm{ml}$ and $\left.\mathrm{KB}, \mathrm{IC}_{50}: 0.54 \mu \mathrm{g} / \mathrm{ml}\right)$.
\end{abstract}

Keywords: Malloapelta B, bimalloapelta, cytotoxicity, electroorganic synthesis

\section{INTRODUCTION}

As part of an ongoing program to discover new anti-cancer agents from nature resources, we have reported previously the isolation and the structural elucidation of malloapelta $\mathrm{B}$, a new cytotoxic compound from Mallotus apelta [1]. To seak malloapelta B's derivatives, which have stronger cytotoxic activities than that of malloapelta $\mathrm{B}$, we have synthesized a series of its derivatives based on organic synthesis and electroorganic reactions.

Currently, electroorganic synthetic method has been numerous using to synthesize organic compounds. The advantages of electroorganic reactions are that they react quickly and very selectivity [2]. Malloapelta B, a new cytotoxic component and new inhibitor againsts NF- $\mathrm{B}$ activation from Mallotus apelta is an organic agent having some double bonds [1]. Therefore, it can be also used as an electroorganic active agent. That means malloapelta B can be oxydated or reduced by electroorganic methods. Among them is the cyclic voltammetric method, which is an efficient synthetic way. In our experiment we chose the voltage located in oxydation area. The voltammograms of base solvent as well as research solvent were taken by electroorganic workstation system IM6 from Zahner Elektrik (Germany) in the voltage range from 1 to $1.5 \mathrm{~V}$ at a scan rate of $150 \mathrm{mV} / \mathrm{s}$. This report deals with the electroorganic synthesis of bimalloapelta (1), the structural detemination and the evaluation of its cytotoxic activity by in vitro assay.

\footnotetext{
* Corresponding author e-mail: ptbinh @ vast.ac.vn
} 


\section{MATERIALS AND METHODS}

\subsection{General experimental procedures}

The IR spectra were obtained on a Hitachi 270 - 30 type spectrometer using $\mathrm{KBr}$ discs. The Electron Spray Ionization Mass (ESI) spectrum was obtained using a AGILENT 1100 LC-MSD trap spectrometer. The ${ }^{1} \mathrm{H}-\mathrm{NMR}(500 \mathrm{MHz})$ and ${ }^{13} \mathrm{C}-\mathrm{NMR}(125 \mathrm{MHz})$ spectra were recorded on a Bruker AM500 FT-NMR spectrometer using TMS as the internal standard. Column chromatography (CC) was performed on silica gel (Kieselgel 60, 70 - 230 mesh and 230 - 400 mesh, Merck). Thin layer chromatography (TLC) was performed on DC-Alufolien Kiesegel 60 F254 (Merck).

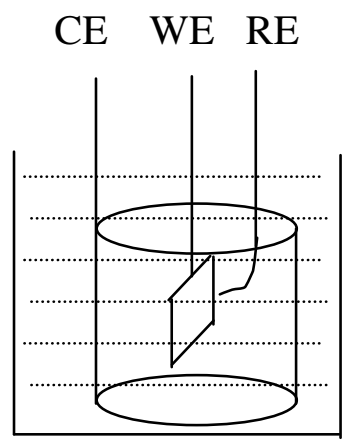

Fig. 1: Electrochemical cell.

\subsection{Synthesis}

Electroorganic cell: Using Electroorganic cell $(100 \mathrm{ml})$ in three electrodes compartment with a platine net as counter electrode (CE), a platine plate of $1 \mathrm{~cm}^{2}$ as working electrode (WE), and a $\mathrm{Ag} / \mathrm{AgCl}$ electrode as reference electrode (RE).

Electrolyte: Base electrolyte was acetonitril with $\mathrm{LiClO}_{4} 0.1 \mathrm{M}$ as supporting electrolyte.

$200 \mathrm{mg}$ Malloapelta B agent (12 g/l) was added to base electrolyte.

Cyclic voltammetry: The current-potential curves (Fig. 3) obtained by the application of a triangular impulse of potential was shown in Fig. 2. Investigations of electrosynthesis by cyclic voltammetry are usually carried out by choosing the voltage spans and sweep rates. The voltammograms were taken using electroorganic workstation system IM6 from Zahner Elektrik unit (Germany) in the voltage range from 1 to $1.5 \mathrm{~V}$ at a scan rate of $150 \mathrm{mV} / \mathrm{s}$ (2000 cycles).

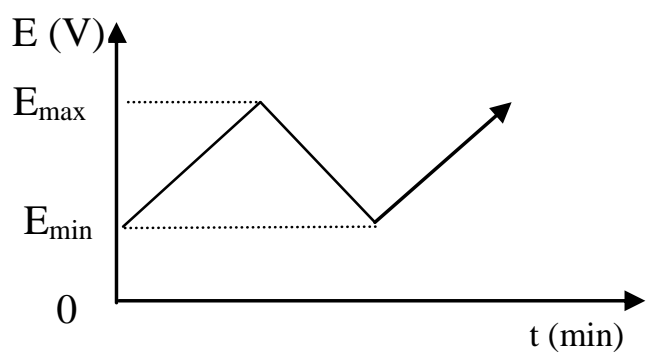

Fig. 2: Variation of applied potential with time in cyclic voltammetry shows the maximum $\left(E_{\max }\right)$ and minimum $\left(E_{\text {min }}\right)$ potentials. The sweep rate $|\mathrm{dE} / \mathrm{dt}|=v$. 


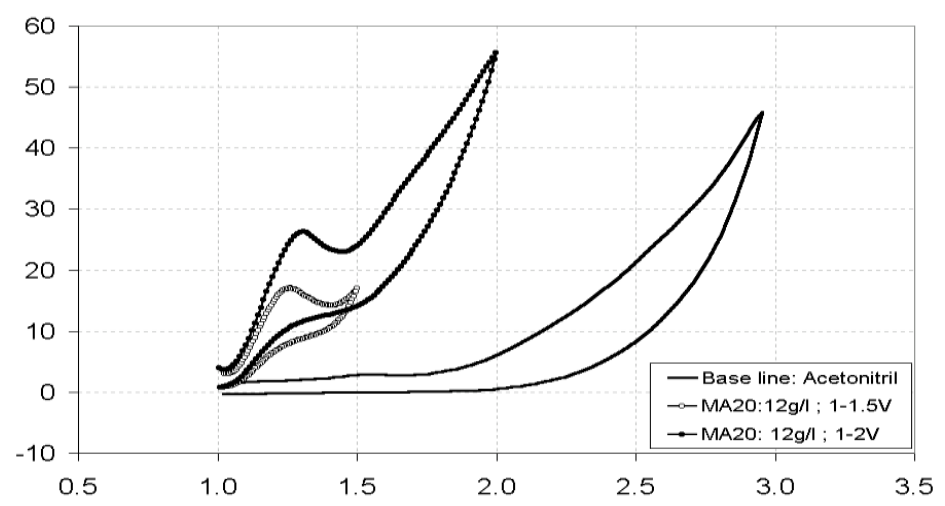

Fig. 3: Cyclic voltammograms from mallopelta $\mathrm{B}$ (MA20) in $\mathrm{LiClO}_{4} \mathrm{O} .1 \mathrm{M}+\mathrm{CH}_{3} \mathrm{CN} 0.1 \mathrm{M}$ ).

\subsection{Purification}

After finishing reaction, the reactive solvent was evaporated in vacum to get $250 \mathrm{mg}$ extract, which was then chromatographed on a silica gel column $(\Phi 20 \times \mathrm{L} 500 \mathrm{~mm})$ eluted with hexane-acetone $(4: 1)$ as the eluent to give $\mathbf{1}(180 \mathrm{mg})$ as white powder.

\subsection{Bimalloapelta (1)}

White powder, IR ${ }^{\mathrm{KBr}} v_{\max } \mathrm{cm}^{-1}: 1745(\mathrm{C}=\mathrm{O}), 1625(\mathrm{C}=\mathrm{C})$; positive ESI $(\mathrm{m} / z) 593[\mathrm{M}+\mathrm{H}]^{+}$; The ${ }^{13} \mathrm{C}-\mathrm{NMR}(125 \mathrm{MHz})$ and ${ }^{1} \mathrm{H}-\mathrm{NMR}(500 \mathrm{MHz})$ : see Table 1.

\section{Cytotoxicity}

The cytotoxic activities of compounds 1 and malloapelta B were assayed on Hep-2 (human hepatocellular carcinoma) and RD (rhabdosarcoma) cells by SRB method [4 - 6]. In brief, the cell lines were stored in the liquid $\mathrm{N}_{2}$, then were cultured in Dulbeco's Modified Eagle Medium (DMEM) suplemented with $7-10 \%$ Fecal Bovine Serum (FBS) for test. Cells were typically grown to $60 \%-70 \%$ confluence, the medium was then changed and the cells were used for test procedures one day later. In each case, 96-well tissue culture plates were used. Test samples (4$10 \mathrm{mg}$ ) were initially dissolved in $1 \mathrm{ml}$ of $100 \%$ DMSO, then diluted 10 fold with $\mathrm{H}_{2} \mathrm{O}$. Serial dilutions were performed using $10 \%$ aqueous DMSO as the solvent, and $10 \mu 1$ were added to each well. Control groups were also added in which $10 \mu \mathrm{l}$ of $10 \%$ DMSO and $10 \mu \mathrm{l}$ of $0,01 \mathrm{mM}$ Elipticine in DMSO were added to each well as negative and positive control in turn. After the plates were prepared, cell were removed from the tissue culture flasks by treatment with Tripsin $0.05 \%$, enumerated, and diluted with fresh media. The quantities of cells (in $190 \mu 1$ of media) were added to the 96 -well plates (KB: $3 \times 10^{4}$; Hep-G2 and FL: $4 \times 10^{4}$ ), and incubation were perform for three days at $37^{\circ} \mathrm{C}$ in a $\mathrm{CO}_{2}$ incubator with the plates capped in the nornal fashion. After the incubation period, cell were fixed to the plastic substratum by the addition of $50 \mu \mathrm{l}$ of cold $50 \%$ aqueous Trichloroacetic acid (TAC). The plate were incubated at $4^{\circ} \mathrm{C}$ for $1 \mathrm{~h}$, washed with tap water $(4 \times)$, and air-dried. Cells then were stained by the addition of $0.4 \%$ Suforhodamine B (w/v) dissolved in 1\% AcOH (30 min). Free sulforhodamine B solution were then removed by washing with $1 \%$ aqueous $\mathrm{AcOH}(4 \times)$. The plates were air-dried, and the bound dye was solubilized by the addition of $10 \mathrm{mM}$ unbuffered Tris base, $\mathrm{pH} 10$. The plates were placed on a shake for $5 \mathrm{~min}$, and the absorption was determined at $515 \mathrm{~nm}$ using an ELISA plate reader. 


\section{RESULTS AND DISCUSSION}

As known about the electroorganic reactions that cation radicals, carboniums or uncharged radicals are formed at the anode, and anion radiacals, carbanions, or uncharged radicals are formed at the cathode [2]. Figure 3 showed the cyclic voltammograms of the solution with and without malloapelta $\mathrm{B}$ in acetonitril plus $\mathrm{LiClO}_{4}(0.1 \mathrm{M})$ as supporting electrolyte. There was a clear appearence of the oxidation peak of malloapelta $\mathrm{B}$ when the potential ranged from 1 to 1.5 $\mathrm{V}$ versus $\mathrm{Ag} / \mathrm{AgCl}$. Some derivatives of malloapelta $\mathrm{B}$ were formed during oxidation process. The main product among them was found. The electroorganic reaction could be:

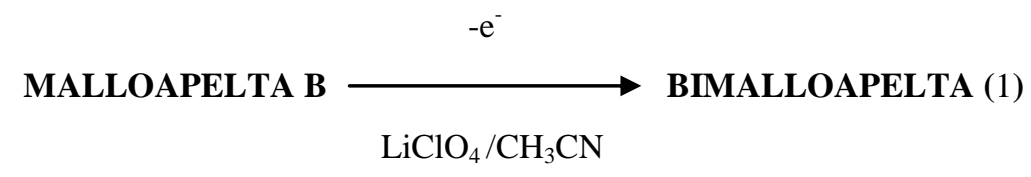

An electroorganic oxidation mechanism of malloapelta B was proposed as shown in Scheme $\mathbf{1 .}$ Firstly, malloapelta B transfered one electron to convert into corresponding cation radical, which was further oxidated by $\mathrm{LiClO}_{4},\left(\mathrm{LiClO}_{4}\right.$ is much oxidative than $\left.\mathrm{CH}_{3} \mathrm{CN}\right)$ then converted into 1 .<smiles>C/C=C/C(=O)c1c(OC)cc(OC)c2c1OC(C)(C)C=C2</smiles>

Scheme 1: The electroorganic oxidation mechanism of malloapelta B.

By chromatography on silica gel, compound $\mathbf{1}$ was obtained as white powder from the reactive solution. The ${ }^{1} \mathrm{H}-\mathrm{NMR}$ spectrum of $\mathbf{1}$ inhibited one singlet of two methyl groups at $\delta 1.33$, one doublet of doublet of the other methyl group at $\delta 1.87(\mathrm{~J}=7.0,1.5 \mathrm{~Hz})$, one singlet at $\delta 6,09$ was assigned to H-6, a doublet of doublet at $\delta 6.30(\mathrm{~J}=15.5,1.5 \mathrm{~Hz})$ and a doublet of quartet at 6.55 $(\mathrm{J}=15.5,7.0 \mathrm{~Hz})$ were assigned to two proton $\mathrm{H}-14$ and $\mathrm{H}-15$, respectively at trans configuration. Two other singlets at 3.81 and 3.78 were assigned to two methoxyl groups. A methine proton resonanced at higher field $(\delta 2.33, \mathrm{~d}, \mathrm{~J}=6.5 \mathrm{~Hz})$ coupled with the other methine proton bearing to oxygen atom at $\delta 4.89(\mathrm{~d}, \mathrm{~J}=6.5 \mathrm{~Hz})$. The ${ }^{13} \mathrm{C}-\mathrm{NMR}$, DEPT $135^{\circ}$ and DEPT $90^{\circ}$ spectra of 1 confirmed the present of 17 carbon, including 3 methyl, 2 methoxyl, 5 methine and 7 quartenary carbon groups. Comparing the NMR of 1 with that of malloapelta B suggested the quite difference between them at C-3 and C-4 of the benzopyran ring. The double bond at C$3 / \mathrm{C}-4$ of malloapelta $\mathrm{B}\left(\delta_{\mathrm{H}} 5.45\right.$ and $6.58 ; \delta_{\mathrm{C}} 127.1$ and 116.7$)$ was oxydated and changed into single bond $\left(\delta_{\mathrm{H}} 2.33\right.$ and $4.89 ; \delta_{\mathrm{C}} 47.8$ and 68.2) in 1. All the other NMR signals of 1 were similar to that of malloapelta $\mathrm{B}$. In addition, the positive electron spray ionization mass spectrum (ESI) of $\mathbf{1}$ inhibited a quasi-molecular ion peak with the highest intensity at $\mathrm{m} / \mathrm{z}, 593$ $[\mathrm{M}+\mathrm{H}]^{+}$, correspond to the molecular formula of $\mathrm{C}_{34} \mathrm{H}_{40} \mathrm{O}_{9}$. This evidence suggested the chemical structure of $\mathbf{1}$ as shown in Fig 4. To further confirm this structure, the heteronuclear 
multiple quantum coherence (HMQC) and heteronuclear multiple bonds correlation (HMBC) spectra were taken and analysed in detail as shown in Table 1. Cross peaks were observed between the methine proton at $\delta 2.33$ and carbon C-4 ( $\delta 68.2) / \mathrm{C}-10(\delta 104.2) / \mathrm{C}-11(\delta 27.3)$, between the oxymethine proton at $\delta 4.89$ and carbon C-2 ( $\delta$ 77.2)/ C-5 ( $\delta 160.8) / C-9(\delta 153.0)$ in the HMBC spectrum indicating further that the double bond at C-3/C-4 of malloapelta B was oxydated and changed into single bond in $\mathbf{1}$. The coupling constant between protons $\mathrm{H}-3$ and $\mathrm{H}-$ $4\left(J_{3-4}=6.5 \mathrm{~Hz}\right)$ confirmed that they are all axial configuration (Silverstein, 1998). Accordingly, the structure of $\mathbf{1}$ was determined as shown in Fig. 4, which named bimalloapelta.

Table 1: NMR spectral data for 1 (measured in acetone- $d_{6}$ ).

\begin{tabular}{llll}
\hline $\mathbf{C}$ & $\boldsymbol{\delta}_{\mathbf{C}}(\mathbf{p p m})$ & $\boldsymbol{\delta}_{\mathbf{H}}(\mathbf{p p m})$ & HMBC \\
\hline $2,2^{\prime}$ & $77.2(\mathrm{~s})$ & - & \\
$3,3^{\prime}$ & $47.8(\mathrm{~d})$ & $2.33(2 \mathrm{H}, \mathrm{d}, \mathrm{J}=6.5 \mathrm{~Hz})$ & $\mathrm{C}-2, \mathrm{C}-4, \mathrm{C}-10, \mathrm{C}-11, \mathrm{C}-12$ \\
$4,4^{\prime}$ & $68.2(\mathrm{~d})$ & $4.89(2 \mathrm{H}, \mathrm{d}, \mathrm{J}=6.5 \mathrm{~Hz})$ & $\mathrm{C}-2, \mathrm{C}-3, \mathrm{C}-5, \mathrm{C}-9, \mathrm{C}-10, \mathrm{C}-4$ \\
$5,5^{\prime}$ & $160.8(\mathrm{~s})$ & - & \\
$6,6^{\prime}$ & $88.5(\mathrm{~d})$ & $6.09(2 \mathrm{H}, \mathrm{s})$ & $\mathrm{C}-5, \mathrm{C}-7, \mathrm{C}-8, \mathrm{C}-10$, \\
$7,7^{\prime}$ & $158.3(\mathrm{~s})$ & - & \\
$8,8^{\prime}$ & $111.2(\mathrm{~s})$ & - & \\
$9,9^{\prime}$ & $153.0(\mathrm{~s})$ & - & \\
$10,10^{\prime}$ & $104.2(\mathrm{~s})$ & - & \\
$11,11^{\prime}$ & $27.3(\mathrm{q})$ & $1.33(6 \mathrm{H}, \mathrm{s})$ & $\mathrm{C}-2, \mathrm{C}-3$ \\
$12,12^{\prime}$ & $24.7(\mathrm{q})$ & $1.33(6 \mathrm{H}, \mathrm{s})$ & $\mathrm{C}-2, \mathrm{C}-3$ \\
$13,13^{\prime}$ & $194.5(\mathrm{~s})$ & - & \\
$14,14^{\prime}$ & $134.4(\mathrm{~d})$ & $6.30(2 \mathrm{H}, \mathrm{dd}, \mathrm{J}=15.5,1.5$ & $\mathrm{C}-8, \mathrm{C}-13, \mathrm{C}-16$ \\
& & $\mathrm{~Hz})$ & \\
$15,15^{\prime}$ & $144.6(\mathrm{~d})$ & $6.55(2 \mathrm{H}, \mathrm{dq}, \mathrm{J}=15.5,7.0$ & $\mathrm{C}-13, \mathrm{C}-16$ \\
& & $\mathrm{~Hz})$ & \\
$16,166^{\prime}$ & $18.2(\mathrm{q})$ & $1.87(6 \mathrm{H}, \mathrm{dd}, \mathrm{J}=7.0,1.5$ & $\mathrm{C}-14, \mathrm{C}-15$ \\
$5-\mathrm{OCH}_{3}$ & & $\mathrm{~Hz})$ & \\
$5^{\prime}-\mathrm{OCH}_{3}$ & $56.9(\mathrm{q})$ & $3.81(6 \mathrm{H}, \mathrm{s})$ & $\mathrm{C}-5$ \\
$7-\mathrm{OCH}_{3}$ & & & \\
$7^{\prime}-\mathrm{OCH}_{3}$ & $56.8(\mathrm{q})$ & $3.78(6 \mathrm{H}, \mathrm{s})$ & \\
\hline
\end{tabular}

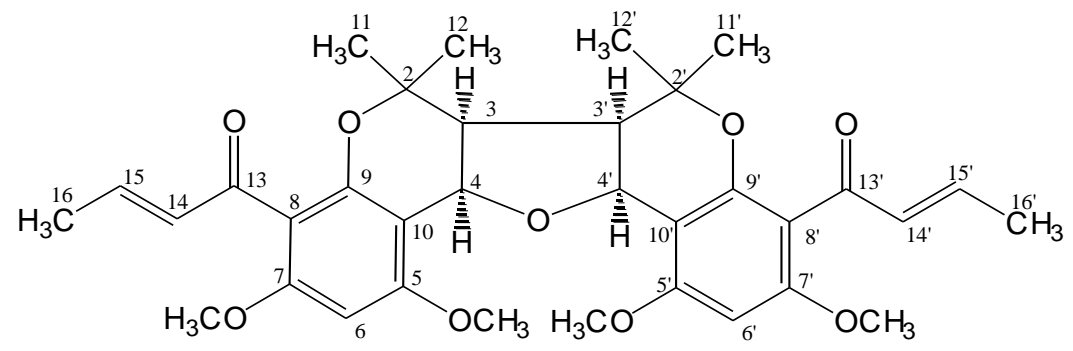

Fig. 4: Structure of compound 1. 
Compounds 1 and malloapelta B were assayed on Hep-2 (human hepatocellular carcinoma) and RD (rhabdosarcoma) cells by SRB method. As a result, 1 also inhibited strongly cytotoxic activity on both tested cancer cell lines Hep-2 and RD with the $\mathrm{IC}_{50}$ values of $0.46 \mu \mathrm{g} / \mathrm{ml}$ and $0.33 \mu \mathrm{g} / \mathrm{ml}$, respectively. Comparing these results with those of malloapelta B (Hep-2, $\mathrm{IC}_{50}$ : $0.49 \mu \mathrm{g} / \mathrm{ml}$ and $\left.\mathrm{KB}, \mathrm{IC}_{50}: 0.54 \mu \mathrm{g} / \mathrm{ml}\right)$ indicated that $\mathrm{IC}_{50}$ values of both compounds were the same and that the oxydation of double bond at C-3/C-4 did not affect to its cytotoxic activity.

\section{ACKNOWLEDGEMENT}

The authors wish to thank the Humboldt-Fellowship for the support of the IM6 equipment. We are grateful to the colleagues of NMR and LC-MS Lab, Institute of Chemistry, VAST for the measurements of NMR and ESI spectra.

\section{REFERENCES}

1. Minh, C.V., Kiem, P.V., Huong, H.T., Nam, N.H., Lee, J.J., and Kim, Y.H. (2005), Chemical investigations and biological studies of Mallotus apelta, VI. Cytotoxic constituents from Mallotus apelta, Journal of Chemistry, vol. 43(1), pp. v-vi.

2. Weinberg, N.L. (1974), Technique of electroorganic synthesis, John Wiley \& Sons Press, vol. V, part I.

3. Silverstein, R.M. and Webster, F.X. (1998), Spectrometric Identification of Organic Compounds, Six Edition, John Wiley \& Sons, Inc. Press, p. 212.

4. Lee, H.J., Park, S.Y., Kim, J.S., Song, H.M., Suh, M.E., and Lee, C.O. (2003). Bioorg. Med. Chem., vol. 11, pp. 4791-4796.

5. Likhitwitayawuid, K., Angerhofer, C.K., Cordell, G.A., and Pezzuto, J.M. (1993), J. Nat. Prod., 56, pp. 30-38.

6. Minh, C.V., Kiem, P.V., Huong, L.M., and Kim, Y.H. (2004), Archives of Pharmacal Research, 27, pp. 734-737. 